\title{
Additive manufacturing methods, materials and medical applications - the review
}

Dorota LASKOWSKA, Katarzyna MITURA, Ewa ZIÓŁKOWSKA, Błażej BAŁASZ

DOI: $10.30464 /$ jmee.2021.5.1.15

Cite this article as:

Laskowska D., Mitura K., Ziółkowska E., Bałasz B. Additive manufacturing methods, materials and medical applications - the review. Journal of Mechanical and Energy Engineering, Vol. 5(45), No. 1, 2021, pp. 15-30.

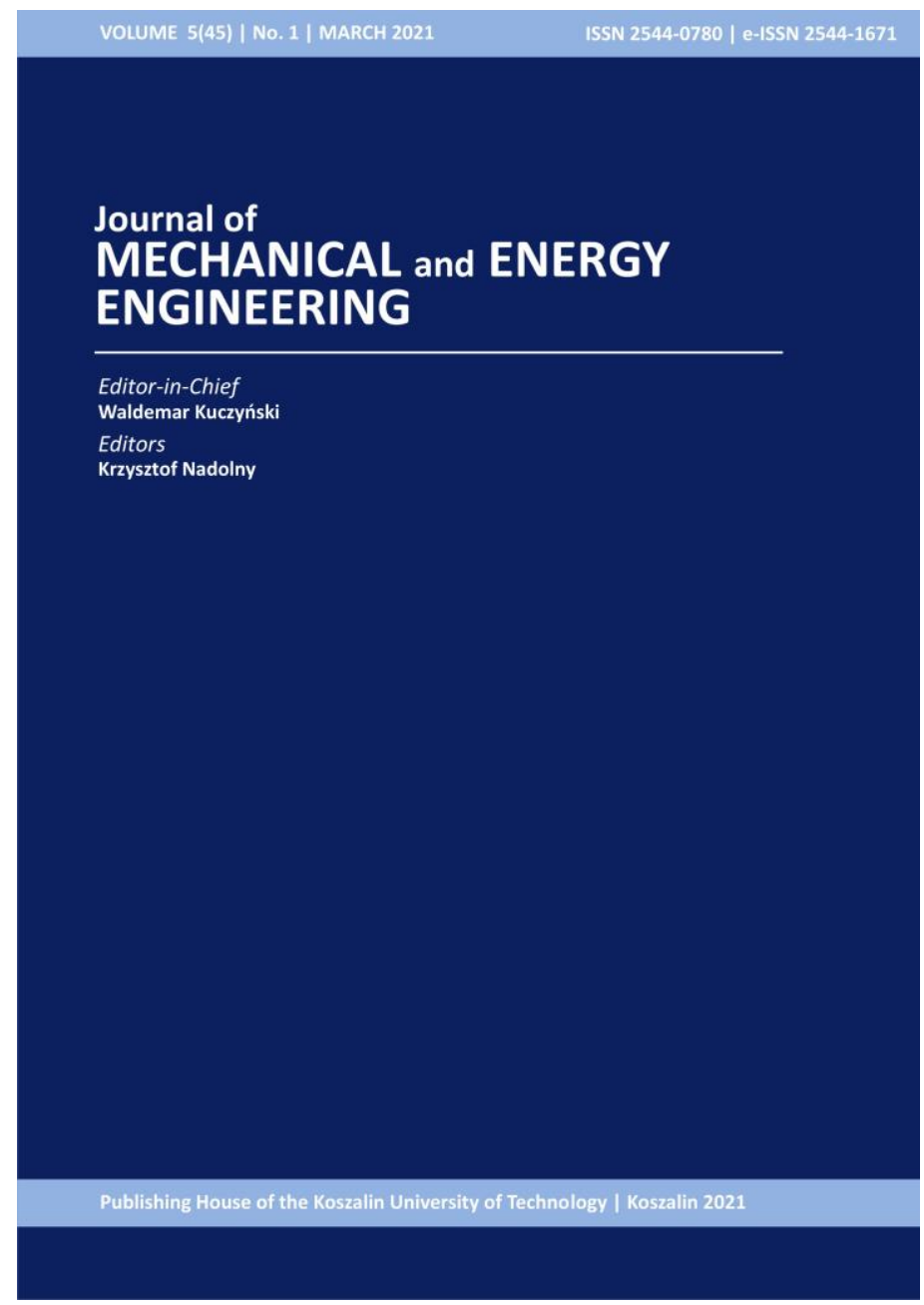

Journal of Mechanical and Energy

Engineering

Website: jmee.tu.koszalin.pl

ISSN (Print): 2544-0780

ISSN (Online): 2544-1671

Volume: 5(45)

Number: 1

Year: 2021

Pages: $15-30$

Article Info:

Received 17 March 2021

Accepted 31 March 2021

\section{Open Access}

This article is distributed under the terms of the Creative Commons Attribution 4.0 (CC BY 4.0) International License (http://creativecommons.org/licenses/by/4.0/), which permits unrestricted use, distribution, and reproduction in any medium, provided you give appropriate credit to the original author(s) and the source, provide a link to the Creative Commons license, and indicate if changes were made. 


\title{
ADDITIVE MANUFACTURING METHODS, MATERIALS AND MEDICAL APPLICATIONS - THE REVIEW
}

\author{
Dorota LASKOWSKA $^{1 *}$, Katarzyna MITURA², Ewa ZIÓŁKOWSKA³ , Błażej BAŁASZ² \\ ${ }^{1 *}$ Faculty of Mechanical Engineering, Koszalin University of Technology, Śniadeckich 2, 75-453 Koszalin, \\ Poland, e-mail: dorota.laskowska@tu.koszalin.pl \\ ${ }^{2}$ Faculty of Mechanical Engineering, Koszalin University of Technology, Poland \\ ${ }^{3}$ Faculty of Health Sciences, Calisia University, Nowy Świat 4, 62-800 Kalisz, Poland
}

(Received 17 March 2021, Accepted 31 March 2021)

\begin{abstract}
The aim of the additive manufacturing (AM) is a production of physical objects by adding material layer-by-layer based on virtual geometry developed in the computer system. The main criteria for the division of additive manufacturing methods are the way to apply the layer and the type of construction material. In most projects, the choice of method is a compromise between costs and properties (e.g. physical, chemical or mechanical) of the manufactured object. Currently, AM methods have found application in many areas of life, including industrial design, automotive, aerospace, architecture, jewellery, medicine and veterinary medicine, bringing many innovative and revolutionary solutions. The purpose of this article is to review of the additive production methods and present the potential of medical application.
\end{abstract}

Keywords: additive manufacturing, preoperative planning, tissue engineering, metal implants

\section{INTRODUCTION}

According to the definition proposed by American Society for Testing of Materials (ASTM) additive manufacturing (AM) is "process of joining materials to make parts from 3D model data, usually layer upon layer, in contrast to subtractive manufacturing and formative manufacturing methodologies". In literature AM is also referred to as 3D Printing, Solid Freedom Fabrication (SFF), Layered Manufacturing (LM) or Rapid Prototyping (RP) [1, 2].

This technology has been developed by Charles Hull in 1986 in a process known as stereolithography. In the initial phase of development, it was a tool to support mass production and to reduce the cost or time of the prototyping stage. Currently, there are many additive manufacturing techniques, which differ mainly in the type (e.g. metal, ceramic, polymer) and form (e.g. powder, sheet, wire, liquid) of the construction material (feedstock) and the process of its solidification. They have found application in many areas of life, including industrial design, automotive, aerospace, architecture, jewellery, medicine and veterinary medicine, which resulted in many innovative and revolutionary solutions.
The main advantages, which influenced the growing interest of $\mathrm{AM}$ are:

- personal customization,

- fabrication of complex geometry with high precision,

- reduction of the feedstocks consumption and possibility of its recycling,

- flexibility in design.

However, this technology has disadvantages, which limit the potential of large-scale additive manufacturing production. To the most important are:

- inferior mechanical properties and anisotropic behaviour of additively manufactured parts,

- dependence of manufacturing precision on the various factors, e. g. printing environment, feedstocks properties or process parameters,

- the need for post-processing to increasing the surface or mechanical properties of the parts,

- limited materials range.

The purpose of this article is to review of the additive manufacturing methods and present the potential of medical application. 


\section{ADDITIVE MANUFACTURING TECHNIQUES}

There are two main categories of additive manufacturing techniques:

- cellular, which includes printing of live cells along with other materials,

- acellular, which includes printing materials without any live cells [2].

The ASTM classification divides acellular AM techniques into seven groups: binder jetting, direct energy deposition (DED), material extrusion, material jetting, powder bed fusion (PBF), sheet lamination and vat polymerization (Fig. 1). In some cases, the additively manufactured objects are post-processed to improve the microstructure, finish surfaces, reduce porosity and roughness or meet geometric tolerance [3].

Tab. 1 is a summary of materials, advantages and disadvantages of the main methods of additive manufacturing.

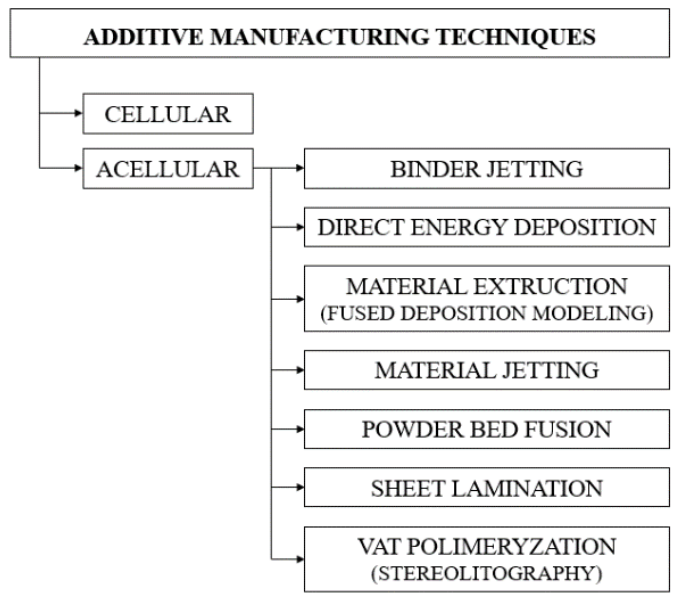

Fig. 1. Classification of additive manufacturing techniques

\subsection{Binder jetting $(\mathbf{B J})$}

Binder jetting technology was developed at the Massachusetts Institute of Technology (MIT) and patented in 1993. In this technique, the object (model) is created by spreading the liquid binding agent onto a selected surface area of the powder bed [2-5].

The main construction materials in binder jetting technique are sand, ceramic and metal, which must be formed into powders for certain binder interaction. Depending on the powder form, dry and wet binder jetting are distinguished. In the dry system, the powder must be dry and compact to have a good layer spreading. In the wet system, the powder is mixed with a liquid carrier to form a homogeneous slurry.

The basic classification divides binders for organic and inorganic. The first type binds the powder via the curing process and the second- via colloid gel formation. The other classifications distinguish groups of binders such as: acid-base, metal salts and solvent binders or in-bed, phase-changing, sintering inhibition binders [2].

Fig. 2 presents the binder jetting process. The typical BJ printer consists of four main parts:

- feed stage,

- levelling roller,

- build stage (work platform),

- binder jetting head.

The role of the levelling rollers is to feed a new powder or slurry layer (from the feed stage to build stage) without distributing the previous layers. Typical for the dry powder system are traversing counterrotating roller (most often used), charged plates, traversing doctor blades and rotating sieve drums. The slurry is usually spread by slip casting. The differences between the binder jetting printers also apply to the mechanism of the printer head. There are two types of print head drop-on-demand (DoD), in which the binder drops are dispensed on-demand, and continuous-jet $(\mathrm{CJ})$, which produces continuous jetting of binder [2, 4].

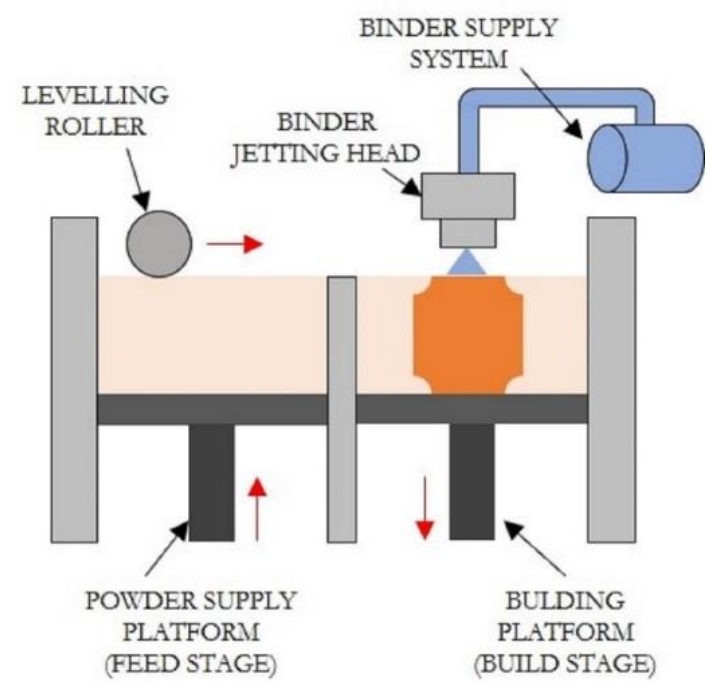

Fig. 2. The schematic of the binder jetting process

The printing process can be divided into several steps:

1. Powder and binder preparation.

2. Formation of an excellent powder packing on the powder bed.

3. Applying binder via the print head.

4. Binding the powder- creating the object layer.

5. Lowering the build stage (work platform).

6. Applying the new layer of powder from the feed stage via levelling rollers.

7. Applying binder and repeating the process.

In this way, a box, which should be heated to cure or solidify the binder, is made. Next, the excess powder (which served as a support during the process) is removed in the process called "depowderization". The great advantage is the possibility of reusing 
unconnected powder after its proper preparation. Next, the object is followed by post-processing to strengthen the bond between the powder and the binder, thus improving the density and mechanical property. For the binder jetting typical post-printing processes are heattreated or sintered (conventional in a regular furnace or microwave in a microwave furnace). Some sintered parts are infiltrated with a second material $[2,4]$.

A comprehensive study on the binder jetting technique can be found in Mostafaei et al [4] and Gibson et al. [5].

\subsection{Direct energy deposition}

Techniques in which use a source of energy (laser or electron beam) directly focused on a selected surface area of material are referred to as direct energy deposition (DED). This solution allows for simultaneously depositing, melting and solidifying the material which can take the form powder, filament or wire [2, 7].

The typical DED system consists of three main parts:

- the focused heat source- laser or electron beam,

- the feedstock injection unit,

- build stage (work platform).

The focused heat source creates a small 'melt pool', into which feedstock material is injected (Fig. 3). It causes growth in volume and mass of the melt pool. This process is repeating for every layer until the full geometry of the object is achieved [8]. The processes coming under DED category can be divided into two main groups:

- techniques for surface modifications, such as laser cladding, laser melt injection and laser engineered net shaping (LENS ${ }^{\mathrm{TM}}$ ),

- for 3D part fabrication, such as direct laser deposition, elect beam direct manufacturing (EBDM) and laser assisted repair [2].

A comprehensive study on the direct energy deposition can be found in Thompson et al. [9], Shamsaei et al. [10] and Gibson et al. [11].

\subsection{Material extrusion and jetting}

Material extrusion is the most popular AM technology, commonly known as fused deposition modelling (FDM). In this technique, the material (as filament) is heated in the nozzle to reach a semi-liquid state and then extruded and continuously deposited on the work table. Therefore this technique is mainly applied for manufacturing from thermoplastics material, such as acrylonitrile butadiene styrene (ABS), polylactic acid (PLA), polycarbonate (PC), polyamide (PA), high-impact polystyrene (HIPS) and poly(oxymethylene) (POM) [2, 7, 12, 13]. Fig. 4 visualizes the FDM printing process.

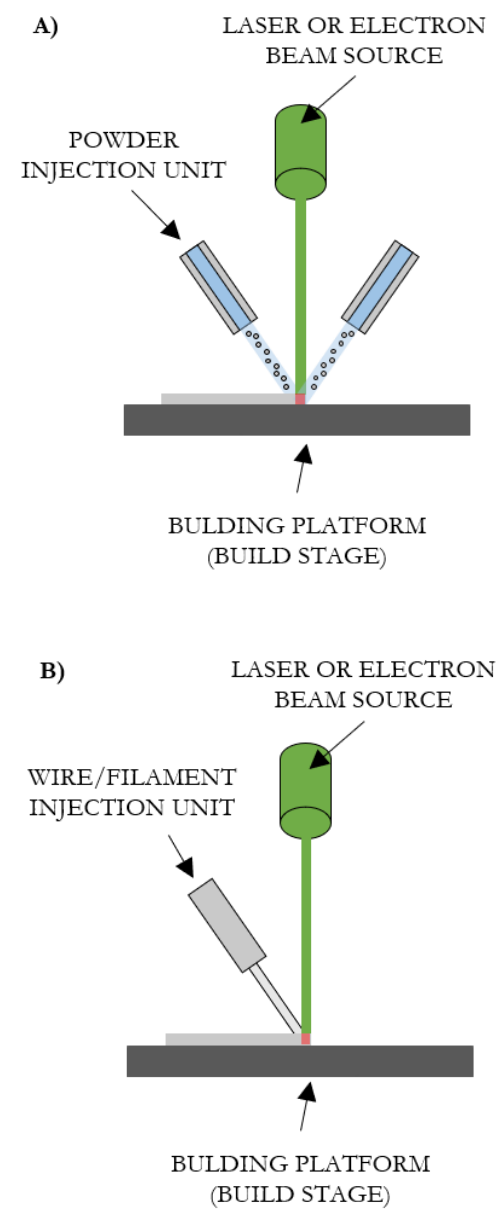

Fig. 3. The schematic of the direct energy deposition: A) powder feedstock; B) wire/filament feedstock

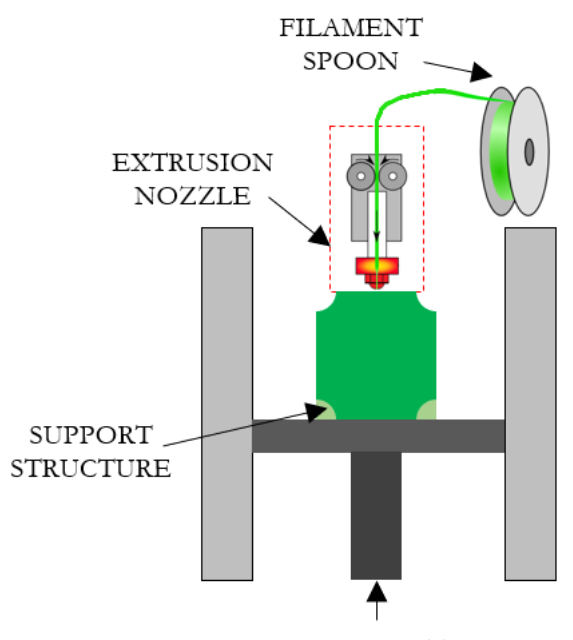

BUILDING PLATFORM

Fig. 4. The schematic of the material extrusion (fused deposition modelling) process 
The printing process can be divided into several steps:

1. Suppling the filament to the extrusion nozzle.

2. Heating the filament in the extrusion nozzle.

3. Depositing the melted filament on a building platform- creating the object layer.

4. Lowering the build stage (work platform).

5. Applying the new layer of melt filament.

The process is repeated until a three-dimensional object is obtained. The biggest disadvantage of the FDM method is the warping, twisting or shrinkage of the models due to the stresses arising during their cooling. Moreover, it is difficult to remove the support material, especially from narrow gaps or holes.

A comprehensive study on the material extrusionbased systems can be found in Daminabo et al. [13] and Gibson et al. [14].

In material jetting (also known as PolyJet) the drops of polymeric materials are deposited on a powder bed and then cured using ultraviolet radiation. This technique allows us to build parts from ultra-thin layers $[2,3]$.

\subsection{Powder bed fusion (PBF)}

Techniques in which use a source of thermal energy (typical laser or electron beam) to fuse a selected area of the surface of the powder is referred to as powder bed fusion (PBF). The typical PBF printer consists of an enclosed chamber with a heat source, scanner, powder bed, powder supply bed, re-coater arm or rake and inter gas supply $[2,6]$. steps:

The printing process can be divided into several

1. Formation of an excellent powder packing on the powder bed

2. Laser scanning and fusing the powder according to the desired design (CAD file)

3. Applying the new layer of powder from the supplied bed via re-coater arm or rake.

4. Repeating the process.

After printing, the excess powder (which served as a support during the process) is removed. The great advantage is the possibility of reusing unconnected powder after its proper preparation. All objects made in the PBF technique require post-processing, and the most important is slow cooling to the room temperature, which role is to prevent the object warping and cracking. The other post-processing are polishing, machining, hot isostatic pressing, shot peening and heat treatment. Their role is giving the object appropriate properties depending on its purpose $[2,6,12]$.

The types of PBF processes are:

- selective laser sintering (SLS),

- selective laser melting (SLM),

- direct metal laser sintering (DMLS),

- selective heat sintering (SHS),

- electron beam melting (EBM).
Both SLS and SLM use a laser source to fuse the powders. However, in SLM the laser completely melts the material to form a homogeneous part, while in SLS the laser heats the powder causing its molecular fuse together at the surface. The DMLS process is similar to that of SLM process. In the EBM the electron beam is used to selectively melt powder in a vacuum environment $[2,15]$. Fig. 5 visualizes the idea of describing PBF systems.

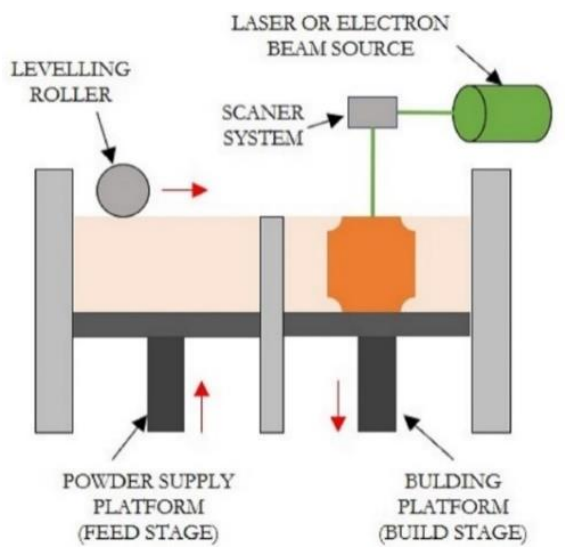

Fig. 5. The schematic of the powder bed fusion processes: SLM, SLS, DMLS or EBM

\subsection{Sheet lamination}

Sheet lamination technique also called laminated object manufacturing (LOM) based on layer-by-layer mechanical or laser cutting of sheets or rolls of the material. The cut layers are laminated and bonded together to form the final object.

Fig. 6 visualizes the sheet lamination process, which can be divided into several steps:

1. Adhering the sheet to the substrate by a heated roller.

2. Laser cutting of part and non-part area (to facilitate waste removal).

3. Lowering the build stage (work platform) and curling the used sheet.

4. Rolling out the fresh sheet of material and adhering with the previous layer.

5. Repeating the process.

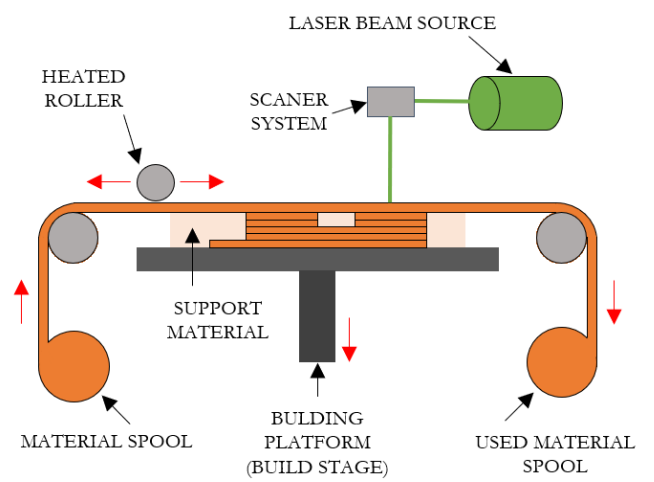

Fig. 6. The schematic of the sheet lamination process 
The excess material serves as a support during the process and afterwards is removed and recycled. Depending on the type of materials or properties, the object manufactured in this technique may require the post-processing, for example high-temperature treatment.

The mainly construction materials used in LOM are polymers, composites, ceramics, paper and metal-filled tapes [7].

\subsection{Vat polymerization}

Vat polymerization (commonly known as stereolithography (SLA)) is the earliest method of AM, which was developed in 1986. In this technique, the layer is formed by the polymerization of a resin or monomer solution with UV light (laser or electron beam). There are two types of polymerization: freeradical and cationic. Free-radical polymerization is characterised by higher reaction speed which is associated with high shrinkage and mechanical failure (for example curling and warping) the manufactured objects. In the case of cationic polymerization, the reaction speed is slower, but risk curling, warping and shrinkage of manufactured objects are smaller. Sometimes it is possible to combine both methods to obtain better results $[2,7]$.

Figure 7 visualizes the SLM printing process, which can be divided into several steps:

1. Formulation of the solution in the vat

2. Immersion of a build platform in a photopolymer liquid

3. Exposure to radiation according to CAD project

4. Polymer solidification and curing of one layer

5. Lowering the build stage (work platform) and repeating the process.

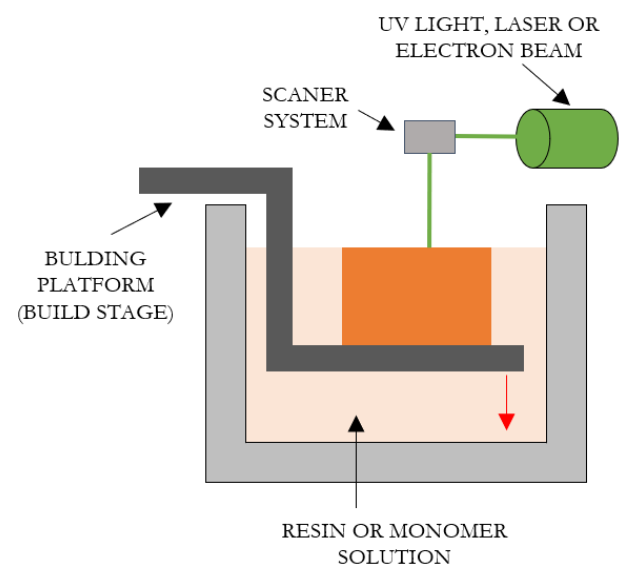

Fig. 7. The schematic of the vat polymerization (stereolithography) process

After printing, the nono-polymerized material is removed. It should be noted that the object is printed with so-called supports, which are waste after removal and cannot always be recycled. The manufactured object requires post-processing, which include three sections: cleaning, post-curing and finishing $[2,7]$

\section{APPLICATIONS IN MEDICINE}

Additive Manufacturing plays an increasingly important role in medicine. The use of various techniques gives a lot of interesting applications, which is widely quoted in the world literature due to its high research and application potential. The fields of medicine in which AM has fund application are among other cardiothoracic surgery, cardiology, gastroenterology, neurosurgery, dentistry, oral and maxillofacial surgery, ophthalmology, otolaryngology, orthopaedic surgery, plastic surgery, podiatry, pulmonology, radiation oncology, transplant surgery, urology and vascular surgery. This technology is used:

- in personalized treatment and preoperative planning,

- to develop customized surgical tools, implants and prostheses,

- to testing different device in specific pathways,

- in improving medical education (for example printed patient-specific models can replace human bodies or storage of rare cases),

- inpatient education,

- to improve forensic practice,

- in the modelling of implantable tissue, so-called bioprinting (for example synthetic skin for the treatment of burn injuries or for testing cosmetics, chemical and pharmaceutical products, replication of heart valves or human ears),

to personalized drug printing $[14,17,18]$.

The Tab. 2 showing a different classification of medical applications of additive manufacturing. With the development of technology, these classifications have become wider and more detailed, but still do not reflect the full spectrum of applications and possibilities. Selected applications of additive manufacturing in medicine are described in the next section of this article.

The process of development in medical applications of additive manufacturing requires close cooperation between the doctor, patient and engineer. It may depend on the area of application, however, a permanent scheme can be developed as shown in Figure 8. The first step is diagnosis and imaging or scanning. By using imaging methods such as computed tomography (CT, the most common), magnetic resonance imaging (MRI), positron emission tomography (PET), ultrasound (USG), optical or laser scanner it is possible to design to obtain the data from various areas of the body, including the skeleton (bones), soft tissues, internal organs or vascular structures.

The medical scans must be transformed from DICOM to STL format (stereolithography or standard tessellation language) by special software. There are several such programs on the market, for example, license Mimics, 3-Matic, Magics and free and opensource 3D Slicer or InVesalius [17, 20-22]. 
In the next step, CAD software is used to design the customized model (e. g. implant, prosthesis, surgical tools) and to make necessary adjustments, for example removing unnecessary tissue or imaging artefacts The usefulness of the designed model is assessed in biomechanical simulation the results of which may decide about the necessity to introduce changes to the model. Many medical devices have strict requirements specified in the national and international law, so the critical stage is getting regulatory approval before manufacturing. Also, patient consent should be obtained before treatment.

In most projects, the choice of additive manufacturing technique is a compromise between costs and the properties (e.g. physical, chemical, biological and mechanical) the manufactured object. In an application-oriented approach, the material, design, and production requirements for the manufactured object must be compatible before the AM phase. Although many devices, the so-called 3D printers, operates automatically specialist expertise is necessary to ensure efficient and accurate results. After the AM phase, some manufactured objects require postprocessing, for example, coating, polishing, or sterilization $[17,20,21]$.

\subsection{Operative planning, educations and training}

One of the most popular applications of additive manufacturing is the production of high-quality anatomical models that enable surgeons to better plan complex operations, as evidenced by the number of literature studies. The mainly AM techniques used to develop models for this type of applications are fused deposition modelling (FDM) and stereolithography (SLA). The examples below are only a few of the possibilities:

- Ganguli et al. [23] presented the application of AM for preoperative planning and surgical training, such as cardiac surgery, neurosurgery, craniomaxillofacial surgery and orthopedic surgery.

- Tong et al. [24] indicated the usefulness of AM in spine surgery, in preoperative uses (such as preoperative planning, patient and trainee education) or in intraoperative uses (such as surgical guides and patient-specific implants).

- Bruns et al. [25] presented the used of additively manufactured pelvic models based on CT or MRI for preoperative planning of partial pelvic replacements (PPR) or a hip transposition procedure (HTP) in cases of oncological patients,

- Jiang et al. [26] presented the used of additively manufactured craniofacial skeletal models based on CT to preoperative planning in case of total or partial inferior border osteotomy for mandibular contouring.,
- Feber et al. [27] described the application of AM for diagnosis and treatment planning for maxillary canine impaction,

- Mishra et al. [28] described the role of virtual preoperative planning and $3 \mathrm{D}$ printing in the treatment of complex orthopedic trauma.

All authors pointed to its great usefulness additively manufactured models but described also their limitations.

\subsection{Diagnostic and surgery instruments}

The development of imaging techniques and the possibility of creating anatomical models allows not only to plan a complex surgical operation but also to design and manufacture customized instruments for diagnostics and surgery. This solution allows to reduce the costs of manufacturing tools, shorten the time of medical procedures and fabricate additional parts for standard devices [18, 29].

Culmone et al. categorized the instruments manufactured via AM techniques considering their novelty into two groups:

- conventional, which design based on traditional instruments,

- unconventional, which are manufactured based on a completely new design; the changes are mostly related to the functionality or size.

Moreover, each of the categories has been divided considering the clinical application into two subcategories: general and specific purpose [29]. This classification and examples are shown in Tab. 3. In Tab. 4 the materials used to this purpose.

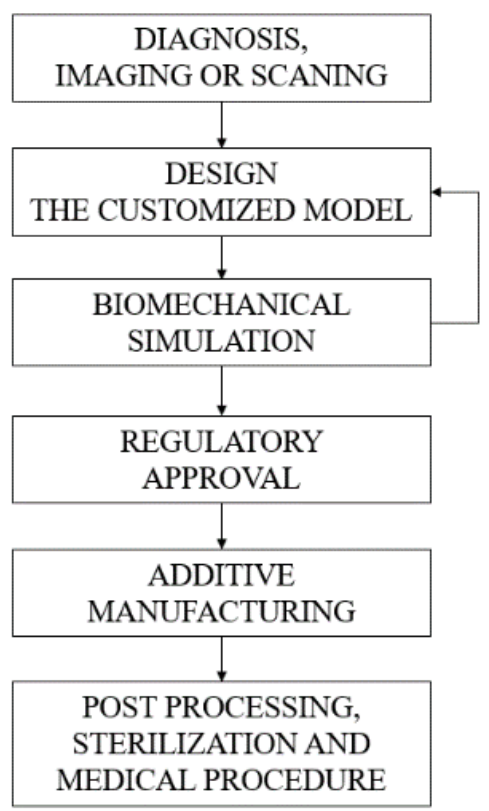

Fig. 8. The process of development in medical applications of AM, based on [17] 
Tab. 1. A summary of materials, advantages and disadvantages of the main methods of additive manufacturing

\begin{tabular}{|c|c|c|c|c|c|}
\hline METHOD & DESCRIPTION & MATERIALS & ADVANTAGES & DISADVANTAGES & REF \\
\hline Binder jetting (BJ) & $\begin{array}{l}\text { The object is created through } \\
\text { spreading the liquid binding } \\
\text { agent onto a selected surface } \\
\text { area of the powder bed }\end{array}$ & $\begin{array}{l}\text { Sand } \\
\text { Metal and metals } \\
\text { alloys powder } \\
\text { Polymers } \\
\text { Ceramics }\end{array}$ & $\begin{array}{l}\text { Low cost, colour printing, excess powder as a support, } \\
\text { different binder-powder combination for various } \\
\text { mechanical properties, large objects, composite } \\
\text { materials }\end{array}$ & $\begin{array}{l}\text { Low strength, requires post-processing, not always } \\
\text { suitable for structural parts, time consuming } \\
\text { depowderization process increases the time of } \\
\text { procedure, powder pose a respiratory hazard }\end{array}$ & $\begin{array}{l}{[7]} \\
{[18]}\end{array}$ \\
\hline $\begin{array}{l}\text { Direct energy } \\
\text { deposition (DED) }\end{array}$ & $\begin{array}{l}\text { The source of energy (laser } \\
\text { or electron beam) directly } \\
\text { focused on a selected surface } \\
\text { area of material is use to its } \\
\text { simultaneously depositing, } \\
\text { melting and solidifying }\end{array}$ & $\begin{array}{l}\text { Metal and metals } \\
\text { alloys in the form } \\
\text { of powder or wire } \\
\text { Ceramics } \\
\text { Polymers }\end{array}$ & $\begin{array}{l}\text { Composite materials, high control of grain structure, } \\
\text { hight-quality, hight accuracy, fully dense parts, } \\
\text { excellent mechanical properties, no need for support, } \\
\text { allow for both multiple-axis deposition and multiple } \\
\text { materials at the same time, combined easily with } \\
\text { conventional subtractive processes to complete } \\
\text { machining, can patch defects on existing objects }\end{array}$ & $\begin{array}{l}\text { Expensive, low resolution, requires post-processing, } \\
\text { limited range of materials, poor surface quality }\end{array}$ & $\begin{array}{l}{[7]} \\
{[16]} \\
{[18]}\end{array}$ \\
\hline $\begin{array}{l}\text { Material extrusion } \\
\text { (fused deposition } \\
\text { modelling, FDM) }\end{array}$ & $\begin{array}{l}\text { The material (as filament) } \\
\text { is heated in the nozzle } \\
\text { to reach a semi-liquid state } \\
\text { and then extruded } \\
\text { and continuously deposited } \\
\text { on the work table }\end{array}$ & $\begin{array}{l}\text { Hydrogels } \\
\text { Thermoplastics } \\
\text { Polymers } \\
\text { Ceramics } \\
\text { Bioinks }\end{array}$ & $\begin{array}{l}\text { Colour printing, low cost, composite materials, open } \\
\text { source designs, simplicity, accessible, widespread, } \\
\text { small technology (office size machine) }\end{array}$ & $\begin{array}{l}\text { Anisotropy, weak mechanical properties, lower } \\
\text { resolution, dependence of quality on the nozzle } \\
\text { radius (bigger nozzle leads to less quality), low } \\
\text { accuracy and dependence on the nozzle thickness, } \\
\text { objects needs support (usually removed } \\
\text { mechanically, which affects the quality of the } \\
\text { surface), lots of material wasted }\end{array}$ & $\begin{array}{l}{[7]} \\
{[16]} \\
{[18]}\end{array}$ \\
\hline $\begin{array}{l}\text { Powder bed fusion } \\
\text { (PBF) }\end{array}$ & $\begin{array}{l}\text { The source of thermal energy } \\
\text { (typical laser or electron } \\
\text { beam) to fuse a selected area } \\
\text { of surface of powder }\end{array}$ & $\begin{array}{l}\text { Limited polymers } \\
\text { Metals and metals } \\
\text { alloys powders } \\
\text { Ceramics }\end{array}$ & $\begin{array}{l}\text { Strong, excess powder as a support, fine resolution, } \\
\text { hight quality }\end{array}$ & $\begin{array}{l}\text { High cost, medium resolution, post-processing } \\
\text { required }\end{array}$ & $\begin{array}{l}{[7]} \\
{[16]} \\
{[18]}\end{array}$ \\
\hline $\begin{array}{l}\text { Sheet lamination } \\
\text { (laminated object } \\
\text { manufacturing, LOM) }\end{array}$ & $\begin{array}{l}\text { The layer-by-layer } \\
\text { mechanical or laser cutting } \\
\text { the material; the cut layers } \\
\text { are laminated and bonded } \\
\text { together to form the final } \\
\text { object }\end{array}$ & $\begin{array}{l}\text { Paper } \\
\text { Polymers } \\
\text { Ceramics } \\
\text { Metals }\end{array}$ & $\begin{array}{l}\text { Low cost, composite materials, no support structure } \\
\text { need }\end{array}$ & $\begin{array}{l}\text { Lots of material wasted, requires post-processing } \\
\text { (delamination), limited material range }\end{array}$ & $\begin{array}{l}{[7]} \\
{[16]} \\
{[18]}\end{array}$ \\
\hline $\begin{array}{l}\text { Vat polymerisation } \\
\text { (stereolithography, } \\
\text { SLA) }\end{array}$ & $\begin{array}{l}\text { The layer is formed by the } \\
\text { polymerization of a resin or } \\
\text { monomer solution with UV } \\
\text { light (or electron beam) }\end{array}$ & Photopolymer resin & $\begin{array}{l}\text { High resolution and accuracy, decent surface finish: } \\
\text { smoother finish, flexible printing setup, complex parts }\end{array}$ & $\begin{array}{l}\text { Lacking in strength and durability, still affected by } \\
\text { UV light after print, not for heavy use, raw material } \\
\text { toxicity, limited material selection }\end{array}$ & $\begin{array}{l}{[7]} \\
{[16]} \\
{[18]}\end{array}$ \\
\hline
\end{tabular}


Tab. 2. Classification of medical applications of additively manufacturing

\begin{tabular}{lll}
\hline \multicolumn{1}{c}{$\begin{array}{c}\text { According to Hopkinson et al. } \\
\text { (2006) [12] }\end{array}$} & According to Tuomi et al. (2014) [20] & \multicolumn{1}{c}{ According to Javaid et al. (2018) [17] } \\
\hline 1. Pre-surgery AM & $\begin{array}{l}\text { 1. Medical models for pre- and } \\
\text { postoperative planning, education and } \\
\text { training }\end{array}$ & $\begin{array}{l}\text { 1. Surgical planning } \\
\text { 2. Medical education and training }\end{array}$ \\
$\begin{array}{l}\text { 2. Orthodontics } \\
\text { 3. Drug delivery devices }\end{array}$ & $\begin{array}{l}\text { 2. Medical aids, orthoses, splints and } \\
\text { prostheses }\end{array}$ & $\begin{array}{l}\text { 3. Design and development of devices and } \\
\text { instrumentation used in medical }\end{array}$ \\
4. Limb prothesis & $\begin{array}{l}\text { 3. Tools, instruments and parts of medical } \\
\text { devices }\end{array}$ & $\begin{array}{l}\text { 4. Customized implant design } \\
\text { 5. In vivo devices }\end{array}$ \\
& $\begin{array}{l}\text { 4. Inert implants } \\
\text { 5. Biomanufacturing }\end{array}$ & $\begin{array}{l}\text { 6. Prosthesis and orthotics } \\
\text { 7. Mechanical bone replicas }\end{array}$ \\
& & 8. Forensics \\
\hline
\end{tabular}

Tab. 3. Classification of medical applications of additively manufacturing

\section{CONVENTIONAL UNCONVENTIONAL}

\begin{tabular}{|c|c|c|c|}
\hline General purpose & Specific purpose & General purpose & Specific purpose \\
\hline $\begin{array}{l}\text { 2. Burr hole } \\
\text { (a device used in intracranial } \\
\text { procedures as the entry port } \\
\text { to stabilize a range of } \\
\text { endoscopic instruments) } \\
\text { 3. General-purpose dental } \\
\text { elevator } \\
\text { 4. Grippers and cutting tools for } \\
\text { integrations into surgical } \\
\text { robots }\end{array}$ & $\begin{array}{l}\text { 1. Reciprocating syringe } \\
\text { 2. Alternative bypass flow } \\
\text { attachment for specific } \\
\text { ventilation imaging } \\
\text { 3. Trocar-cannula for } \\
\text { transconjunctival vitrectomy } \\
\text { 4. Measuring tools } \\
\text { to estimate the size of } \\
\text { a probe used in lumpectomy } \\
\text { 5. Cap to conventional } \\
\text { colonoscope to enhance the } \\
\text { field of view of the } \\
\text { instrument } \\
\text { 6. Cap to conventional } \\
\text { gastroscope } \\
\text { with a different shape } \\
\text { depending on } \\
\text { the medical procedure }\end{array}$ & $\begin{array}{l}\text { 1. Steerable surgical } \\
\text { instruments } \\
\text { (e.g. DragonFlex- } \\
\text { laparoscopic grasper } \\
\text { with a possibility to steer } \\
\text { inside the patient's body) } \\
\text { 2. New designs for } \\
\text { continuum robots and } \\
\text { manipulators based on } \\
\text { snake-like system } \\
\text { 3. A medical instrument } \\
\text { to positioning and } \\
\text { stabilizing systems } \\
\text { 4. Forces sensors } \\
\text { to directly integrate } \\
\text { the sensor into a catheter } \\
\text { or a trocar } \\
\text { 5. Device to trans-anal } \\
\text { endoscopic surgical } \\
\text { procedures (provide } \\
\text { an adequate workspace } \\
\text { without inflating the } \\
\text { rectum) }\end{array}$ & $\begin{array}{l}\text { 3. Customized device } \\
\text { for brachytherapy } \\
\text { 4. Device to perform } \\
\text { a particular gynaecological } \\
\text { surgery (laparoscopic } \\
\text { removal of the uterus) } \\
\text { 5. Tailored handpiece to hold } \\
\text { the scanning fibre endoscope } \\
\text { used to acquire a dental } \\
\text { image } \\
\text { 6. Device to implant cell sheets } \\
\text { after the removal } \\
\text { of gastrointestinal tumours } \\
\text { 7. Overtube system modified } \\
\text { to be suitable for a specific } \\
\text { surgery }\end{array}$ \\
\hline
\end{tabular}

Tab. 4. Classification of medical applications of additively manufacturing

\begin{tabular}{lll}
\hline POLYMER-BASED MATERIALS & \multicolumn{1}{c}{ MATERIALS AND METAL ALLOYS } & CERAMIC MATERIALS \\
\hline - acrylonitrile butadiene styrene & - stainless steel (SS) & - ceramic-filled epoxy resin \\
(ABS) & - titanium (Ti) & - alumina-zirconia composite \\
- polylactic acid (PLA) & - titanium alloy & \\
- polyamides, for example, nylon and & - cobalt-chromium (Co-Cr) alloy & \\
PA2200 & \\
- polycarbonates (PC) & \\
- polycaprolactone (PLC) & \\
- resin & \\
- rubber-line materials & \\
\hline
\end{tabular}


To manufacture medical instruments are used to mainly the additive manufacturing techniques such as material extrusion, powder bed fusion and material jetting. Other techniques (vat polymerization, binder jetting, straight energy deposition and sheet lamination) are used rarely or not at all [29].

The choice of materials is directly related to the technology, properties that the manufactured element should have and the conditions under which this element will be used. The group of materials used most often in this group applications are polymers, due to mainly due to their biocompatibility (as for PLA) and biodegradability (as for PA2200) [29].

Additive manufacturing also offers the possibility of manufacturing devices with enhanced wear resistance, through selectively modification their surface by metal-based intermetallic coatings, by metalceramic hard facing coating or by a metal-ceramic that acts as a solid lubricant during wear [2].

\subsection{Tissue engineering}

Tissue engineering is a field of science that uses medical knowledge and materials engineering for the production of scaffolds which provide structural support for the newly formed tissue. Once again, the use of computational modelling using patient-specific anatomical data and additive manufacturing enables the design of complex biomedical models such as scaffolds, prostheses and implants.

Generally, in tissue engineering cells, which may derive from different sources, including established cell lines, stem cells or primary cells (autologous, allogeneic or xenogeneic), need three-dimensional support, which properties allow cells to easily adhere, their grow and differentiate. So, the success of tissue regeneration depends on the macro-and microstructure of the scaffolds, as well as on the component materials used to their development. It is a complex process during which take place cell-cell and cell-scaffold interactions, both locally and systemically. As research shows, the techniques of additive manufacturing are especially outstanding in developing of scaffolds with both micro-and macroporosity structure. Moreover, the scaffolds must be biocompatibility to allow integration without toxic effects (cytotoxic or genotoxic) and/or immune response [2, 12].

The additive manufacturing techniques used in the manufacture of scaffolds are stereolithography, selective laser sintering, fused deposition modelling and three-dimensional printing (binder jetting). Moreover, in the tissue engineering are used systems, which allow for deposition of cells suspended in bioink, so-called bioprinting systems. There are four major bioprinting systems:

- inject bioprinter, which uses an air pressure pulse generated by heating or piezoelectric pressure to deposit droplets of bioink,
- microvalve bioprinting works by opening and closing a small valve to control the release of bioink from a cartridge under constant pneumatic pressure,

- microextrusion bioprinter, which uses pneumatic or mechanical dispensing systems to continuous extrude of material,

- laser-assisted bioprinter, which uses of laser energy to generate force transfer of droplets of bioink to the substrate [2, 18, 31, 32].

Tissue engineering can be divided into two categories:

- hard tissue engineering, which involves the regenerations of hard tissue such as bones, teeth and cartilage,

- soft tissue engineering, which involves the regenerations of soft tissue such as skin, blood vessels, ligaments and tendons.

It should be noted that in hard tissue engineering the acellular methods have greater use, while in soft tissue engineering the leading technique is bioprinting, which is reflected in the quoted literature and examples provided in the following section.

\subsubsection{Hard tissue engineering}

Hard tissue engineering requires the fabrication of scaffold that are initially capable of supporting the loads until the new tissue is formed. According to Madrid et al. [12] scaffolds used to the regeneration of bone tissue should meet such requirements as:

- biocompatibility,

- porosity, which in addition to ensuring a good cells adhesion, it affects vascularization, diffusion of nutrients and gases, and the removal of metabolic wastes

- chemical and topographic surface properties, which influence on cells adhesion and proliferation,

- osteoinductivity,

- mechanical properties, which depend on the site of implantation and the acting mechanical forces,

- biodegradability, that after full regeneration of tissue the scaffold has completely degraded,

- radiolucency, which allows for an effective assessment of the degree of tissue regeneration, thanks to it radiographically methods.

\section{Examples: bones}

Zafar et al. [33] described the applications of bioceramics-based additive manufacturing in bone tissue engineering. Bioceramics due to their excellent chemical and mechanical properties, such as good osteoconductivity, excellent wear resistance and biocompatibility is gaining more and more interest in the regeneration of bone tissue. The authors of the study mention hydroxyapatite (HA), tricalcium phosphate (TCP) and bioactive glass as one of the most commonly used materials. Among the additive manufactured techniques used to produce ceramic parts, the authors mention the novel stereolithography method (such as 
laser or ceramic stereolithography), extrusion-based methods (such as robocasting), binder jetting and bioprinting.

It also seems interesting the report by Liu et al. [34], which presents a fabrication process of a bone scaffold model with titanium biomedical materials by selective laser sintering. The scaffold was prepared from a slurry, which consists of titanium powder with the average particle size of $10 \mu \mathrm{m}$ and silica sol mixed at 2:1 weight ratio. The metal-ceramic slurry was sintered with laser power of $15 \mathrm{~W}$, layer thickness of $100 \mu \mathrm{m}$ and scanning speed of $100 \mathrm{~mm} / \mathrm{s}$. The total duration of the printing process was about $3 \mathrm{~h}$. Then a high-temperature heat treatment in $700^{\circ}, 800^{\circ}$ and $900^{\circ}$ with 120 min duration was performed, to extreme strength reinforcement. The SEM analyze shown that in the surface of the scaffold were formed a many micro-porous, which allow for cell attachment and growth. The scaffold biocompatibility was assessed by the MTT test for human osteogenic sarcoma (MG63). The study showed that the number of live cells increases with cell culture time. Conclusion, Liu et al. demonstrated the suitability of SLS for the production of scaffolds for bone tissue engineering and indirectly for the production of medical implants using this method.

\section{Examples: cartilages}

Cartilage is a connective tissue made of chondrocytes and extracellular matrix, such as collagen and proteoglycan, which are primary located in joints between bones. In terms of mechanical properties, cartilage tissue is located between the muscles and bones. Its biggest drawback is a poor ability to regenerate itself. In case of damage, pharmacological treatment, microfracture technique, allografting or autografting is applied. However, these techniques have several limitations, for example, requires long term recovery, regenerates damaged tissue to normal function only partially or allows for regeneration only small defect. The way to overcome these limitations is cartilage tissue engineering (CTE) $[2,35]$.

Sherwood et al. [36] described the process of producing CTE scaffolds using the binder jetting technology. The scaffolding consisted of three parts:

- upper fabricated from the PLGA/PLA composite with $90 \%$ porosity

- middle fabricated by transitional composition and porosity between the upper and lower sections

- lower fabricated from the PLGA/TCP composite with $55 \%$ porosity.

The varying porosity was aimed at improving the cell seeding, enhance osteogenesis and mechanical properties. The results of in vitro studies showed that this solution allowed for good adhesion of chondrocytes to the scaffold surface and the formation of new cartilage after 6 weeks.
Camarero-Espinosa et al. [37] reported on the use of additive manufactured scaffolds from poly(ester)urethane (PEU) by fused deposition modelling (FDM). The main advantage of PEU is biodegradability. The manufactured scaffolds had two different structures: $90^{\circ}$ and $60^{\circ}$ deposition patterns and with a pore size of $500 \mu \mathrm{m}$. The structure analysis carried out with the use of SEM and $\mu$ CT showed a high quality of the designed patterns and reproducible and interconnected pore structure with a closed porosity. Next, the human BMSCs, which were isolated from a 22-year-old mane donor, were cultured for 14 and 28 days on PEU scaffolds immersed in differentiation media. Comparative groups were BMSCs cultured on the same scaffold on basal media and as pellets in both conditions. The conducted research $(\mu \mathrm{CT}$ and quantification of DNA) showed that PEU scaffolds showed a good cell invasion and survival after 14 and 28 days. This suggests that the manufactured scaffolds have potential for use in the regeneration of cartilage tissue.

\subsubsection{Soft tissue engineering}

The soft tissue is a special type of tissue composed of elastin, collagen and ground substance, which mainly functions are to connect, support and protect the surrounding structures and organs. Some of the important soft tissue are skin, muscle, tendon, ligament, nerve and blood vessel. Several examples of the use of acellular additive manufacturing methods in soft tissue engineering can be found in the literature. However, bioprinting plays here an increasingly important role [32].

\section{Examples: ligament and tendon}

Additive manufacturing has been used, inter alia, for building tooth-ligament complex. The complex consisted of individual parts:

- periodontal ligament (PDL) with a thickness of 0.8 $\mathrm{mm}$ and a structure with multiple perpendicularly oriented channels, whose purpose was the guidance of fibrous connective tissue formation and alignment of fibroblast-like cells. This part was manufactured from $25 \%$ poly (glycolic acid) (PGA).

- bone compartments with a global porous geometry with dimensions: $0.75 / 0.50 / 0.05 \mathrm{~mm}^{3}$. This part was manufactured from $25 \%$ poly- $\varepsilon$-caprolactone (PLC).

The forms of these parts was a fabrication by vax polymerization system. Both parts were fused a thin layer from $15 \%$ PLC to form one single hybrid scaffold. In the study used a different type of human tissue and cells:

- healthy human teeth, which were extracted from patient in the form of a block with dimensions matching to the PDL parts and was prepared for the purpose to exposed dentinal tubule topology and promote fibrous tissue attachment, 
- primary human gingival fibroblast (hGF) cells,

- human periodontal ligament cells (hPDL).

Tissues and cells were seeded in appropriate compartments of the scaffold. In vivo studies (animal model) showed improved growth of newly formed tooth cementum-like tissue, ligament and bone structures within the tooth-ligament complex, which is promising towards clinical applications.

\section{Examples: blood vessels}

Ciu et al. [39] shown the method of developing human microvasculature from human microvascular endothelial cells (HMVEC) and fibrin by inkjet bioprinting technology. Scaffold with a microchannel structure was prepared for fibrin by a thermal inkjet printer, modified according to the original idea. The SEM analysis of the scaffold shown the many nanofibers. This type of structure allows for the cells to attach and proliferation. Then, the bioink coating HMVEC was printed around the microchannel of the scaffold. The in vivo study showed that the after 21 days of culture the endothelial cells formed a confluent lining along with the fibrin scaffold. On this basis, it was concluded that thermal inkjet printing technology can be a promising approach for the development of human microvasculature in soft tissue engineering.

\subsection{Metallic implants and endoprosthesis}

As statistics show, every year more and more implementations of implants and endoprostheses are performed. The age of patients requiring this type of surgery is also falling, which is associated with an increase in the reoperation

Most of the currently used implants and endoprostheses are made of materials such as stainless steel, titanium and titanium or cobalt-chromium molybdenum alloys, due to their durability, strength, corrosion resistance and low immune response. The traditional manufacturing methods are casting, forging and machining. However, the mechanical properties (in particular stiffness) this type of implants are significantly different in comparison with the mechanical properties of the bone tissue. This can lead to a reduction in bone density, and hence to aseptic loosening of the implants and reoperation. To minimize this risk, it is necessary to maximize osseointegration. This applies in particular to implants with a long stay in the body. On the other hand, the temporary implants should have lower osteointegration that they can be easily removed from the body. As the research results show, the powder bed fusion techniques (such as selective laser melting, selective laser sintering and electron beam melting) allows for the development of implants with controlled or "engineered" porosity whilst simultaneously reducing the effective bulk stiffness [18, 40-42].

Another problem of implantology is a risk of infection initiated by bacterial adhesion and the formation of bacterial biofilm at the implant surface. Such infection is often referred to as periprosthetic infections (PPI) and is difficult to treat because bacterial biofilm reduces the efficacy of antibiotic. AM methods allow manufacturing implants with additional functions, for example in combination with therapeutic agents. This effect is achieved thanks to the infiltration of AM porous structure of the implants or inclusion to the implant of the internal reservoir [40-44].

Other advantages described in the literature are:

- the possibility of producing implants from biocompatible and MRI-compatible materials

- reduction material wastage,

- iterative product redesign without the expense of retooling $[18,40]$.

Unfortunately, the PBF AM processes show unique defects that can affect the mechanical behavior. Moreover, the additively manufactured elements show different microstructural and mechanical behavior compared to conventionally. It can be associated with high heating and cooling rates of material during the printing process and after that.

Other problems are the anisotropy and heterogeneous mechanical response associated with the layered nature of production. Conclusion, the process requires further optimization that the additively manufactured medical implants fulfilled the regulation framework for implantable device [40].

The additively manufactured implant can be divided into two groups mass-manufactured implants and patient-specific implants. The patient-specific implants can be divided from a regulatory perspective into:

- implants with greater flexibility in the size or shape of specific design elements in comparison with conventional mass-manufactured implants, but still fit for broad 'envelope' of design features

- implants produced for atypical clinical needs with a unique design and construction [40].

In the next sections described examples of the patient-specific metal implants used in dentistry and orthopedics.

\section{Examples: dentistry}

A review of the literature shows that the use of additive manufacturing techniques in dentistry offers a lot of benefits and are becoming a new trend. Implants and dental restorations customized to specific patient needs, thereby increasing patient comfort and reducing overall cost and time of the treatment. Cost reduction also applies equipment inventory, which can be stored in digital form and create at any time [45-48].

The most common additive manufacturing techniques used in metal implant dentistry are selective laser sintering (SLS), selective laser melting (SLM) and electron beam melting (EBM). They are used to manufacture for example titanium implants, 
customized subperiosteal titanium implants, customized AM titanium meshes for bone grafting techniques, cobalt-chrome frameworks for implant impression procedures, cobalt-chrome and titanium implant framework for implant-supported prostheses [46-48].

The additive manufacturing methods are used to manufactured elements from other dental materials, such as zirconia, alumina, leucite or ceramic composites [49], but it is not the subject of this section.

The example of customized implants with greater flexibility in the size or shape was presented by Mangao et al. [50]. They described results of treatment with using custom-made subperiosteal implants in cases of elderly patients with the atrophic posterior mandible. Ten patients aged over 65 years were included in the study. The implants were designed based on computed tomography and manufactured from titanium by direct metal laser sintering (DMLS). At the one-year followup no implants were lost, due to incorrect adaptation during surgery and consequent mobilization or instability of the implant, implant fracture, infection, or loss of bone support in the absence of infection.

A small percentage of patients presented immediate postoperative complications and late complications. All these complications were minor and biological nature. Described in this study patientspecific DMLS implants proven to be an effective alternative method for elderly patients with severe bone atrophy, which did not want to or can undergo bone regenerative procedures. However, the authors accentuate need to conduct studies on a larger group of patients and longer follow-up.

In the next study Figliuzzi et al. [51] shown a used of customized root analogue dental implant (RAI) to immediate implantation. The procedure was performed in a 50-year-old female patient with a fractured non-restorable second maxillary right premolar. RAI implant was designed based on CT datasets of the fractured tooth and manufactured from Ti-6Al-4V alloy powder by selective laser melting technique.

Immediately after tooth extraction, the implant was placed in the extraction socket and restored with a single crown. This procedure aims to reduce the marginal bone resorption, that typically follows extraction socket healing. The main advantage is the shortening of the rehabilitation treatment time and the avoidance of a second surgical intervention. However, the condition for successful surgery is to ensure the primary stability of the implant, by its matching it to the fresh extraction socket.

One-year follow-up results have shown that custom made RAI implant was stable, with no signs of infection, such as pain or suppuration. The radiography examination confirmed the good conditions of the peri-implant tissues, with unchanged peri-implant marginal bone level and no peri-implant radiolucency. Implant showed almost perfect functional and aesthetic integration, which confirmed the usefulness of the described solution in dental immediate implantation.

\section{Examples: orthopedics}

As already mentioned, the powder bed fusion methods are the most commonly used to produce metallic orthopaedic implants. There are several commercially mass-manufactured orthopaedic implants produced by AM which have been approved by the Food and Drug Administration (FDA). They are presented in Table 5.

The example of customized implants with greater flexibility in the size or shape was presented by Zang et al. [52]. They attempted to evaluate the safety of treatment the early osteonecrosis of the femoral head (ONFH) with using the additively manufactured the titanium metal trabecular bone reconstruction system (TMTBRS) implant. The implant was manufactured using the electron beam melting (EBM) from Ti6Al4V alloy. Thirty patients participated in the study; each was treated with the TMTBRS implant of the same geometry but different size and length of the extension rods.

Radiological control was performed at 6, 12, and 24 months post-surgery to assess TMTBRS stability and bone growth in the bone trabecular holder portion surface. To evaluate a hip function, postoperative Harris and Visual Analogue Scale (VAS) scores were used. Based on the conducted

The example of customized implants with greater flexibility in the size or shape was presented by Zang et al. [52]. They attempted to evaluate the safety of treatment the early osteonecrosis of the femoral head (ONFH) with using the additively manufactured the titanium metal trabecular bone reconstruction system (TMTBRS) implant. The implant was manufactured using the electron beam melting (EBM) from Ti6Al4V alloy.

Thirty patients participated in the study; each was treated with the TMTBRS implant of the same geometry but different size and length of the extension rods.

Radiological control was performed at 6, 12, and 24 months post-surgery to assess TMTBRS stability and bone growth in the bone trabecular holder portion surface. To evaluate a hip function, postoperative Harris and Visual Analogue Scale (VAS) scores were used. Based on the conducted research, the authors concluded that the treatment with using of additively manufactured TMTBRS implant was effective for early ONFH. The advantage of such a solution was minimal invasiveness of the surgery and modular structure of the implant, that makes it easy to remove and to perform total hip arthroplasty (THA) if needed. 
Tab. 5. Classification of medical applications of additively manufacturing

\begin{tabular}{|c|c|c|}
\hline PRODUCT TYPE & $\begin{array}{l}\text { ATOMICAL } \\
\text { REGION }\end{array}$ & MATERIAL \\
\hline Osteotomy truss & Foot and ankle & \multirow{6}{*}{$\begin{array}{l}\text { Ti-6Al-4V } \\
\text { alloy }\end{array}$} \\
\hline Acetabular cup & Hip & \\
\hline Femoral steam & Hip & \\
\hline $\begin{array}{c}\text { Tibial cavity } \\
\text { reinforcement }\end{array}$ & Knee & \\
\hline Tibial baseplate & Knee & \\
\hline Sacroiliac fusion & Sacroiliac & \\
\hline Interbody fusion & Spinal & $\begin{array}{l}\text { Ti-6Al-4V } \\
\text { alloy } \\
\text { Co-Cr-Mo } \\
\text { alloy }\end{array}$ \\
\hline
\end{tabular}

In the next study, Wang et al. [53] described the use of additively manufactured titanium sleeve-prosthetic composite for the reconstruction of severe segmental bone loss of proximal femur in revision total hip arthroplasty. Due to the aseptic loosening of the prosthesis, in 2013 she underwent a cement revision of total hip arthroplasty. The patient presented to the emergency department on account of acute severe pain of the left hip. The radiological examined shown a severe segmental bone loss of proximal femur and fracture of the prosthetic stem. In the treatment of the described case using the personalized medical implant, which manufactured using electron beam melting (EBM) from titanium. This design was aimed at to facilitate bone and vessels ingrowth, and imitate the biomechanical properties of the host bone. The authors pointed out a few advantages of this solution, in comparison with other standard techniques, such as:

- customization,

- simulation of the native anatomy of host bone, which allows for restore the proximal femoral anatomy and biomechanics,

- maximization the contact surface with host bone, which allow for bone ingrowth, biological fixation of soft tissue sleeve and implant, thus decreasing the risk of dislocation and loosening,

- reduction the stress concentration by similar biomechanical properties of implant and bones, thus decreasing the risk of implant failure.

Two-year clinical and radiological follow-up shown a good integration of the implant at the site of implantation, which may point to clinical usefulness of the applied treatment in other patients with a similar history and stage of advancement. However, the authors point to the need for more studies and longer observation to determine potential complications and long-term survivorship.

\section{CONCLUSION}

This review paper focuses mainly on the medical applications of additive manufacturing. The cited examples show that this technology plays a significant role in preoperative planning education and trending, develop of diagnostic and surgical instruments, design of scaffolds in soft and hard tissue engineering and design of metallic implants and endoprosthesis. The mainly benefits there are:

- customization to patient's or clinical's need,

- considerable reduction in production cost,

- production and assembly time do not increase with the complexity of the design,

- reduction in the number of components while increasing the complexity of single element,

- possibility of manufacturing tools with increased wear resistance,

- possibility of manufacturing scaffolds and implants with height porosity for increased osteoconductive,

- manipulation of the main features of the materials at the micro and nano-metric scale that offers a novel strategy

- to improve the biological and mechanical properties of scaffolds and implants,

- manufacturing instruments with materials compatible with MRI and biocompatibility,

- opportunity to proof of concept (rapid prototyping),

- increased accessibility to healthcare in remote areas, for exampling developing countries, military expedition and space missions.

However, AM techniques have their drawbacks and limitations, such as the limited amount of construction materials (feedstocks) and required of post-processing treatment to improve mechanical or surface properties of manufactured elements. Conducting further research and development works will allow for overcoming these limitations and expanding of AM techniques on a mass scale.

\section{References}

1. ASTM 52900 (2002): Standard Terminology for Additive Manufacturing-General Principles-Part 1: Terminology. American Society for Testing of Materials.

2. Bose S., Ke D., Sahasrabudhe, H., Bandyopadhyay A. (2018). Additive manufacturing of biomaterials Progress in Material Science, Vol. 93, pp. 45-11.

3. Bourell D., Kruth J.P., Leu M., Levy G., Rosen D., Beese A.M., Clare A. (2017). Materials for additive manufacturing. CIRP Annals- Manufacturing Technology, Vol. 66, pp. 659-681.

4. Mostafaei A., Elliot A.M., Barnes J.E., Li F., Tan W., Cramer C.L., Nandwana P., Chmielus M. (2021), Binder jet 3D printing- Process parameters, materials, properties, modeling, and challenges. Progress in Materials Science, Vol. 119, 100707.

5. Gipson I., Rosen D., Brent S. (2015). Binder Jetting. In Additive Manufacturing Technologies: 3D Printing, Rapid Prototyping, and Direct Digital Manufacturing 
(Gipson I., Rosen D., Brent S., Eds.). Springer, New York, USA, pp. 205-208.

6. Cooke S., Ahmadi K., Willerth S., Herring R. (2020). Metal additive manufacturing: Technology, metallurgy and modelling. Journal of Manufacturing Processes, Vol. 57, pp. 978-1003.

7. Ngo T.D., Kashani A., Imbalzano G., Nguyen K.T.Q., Hui D. (2018). Additive manufacturing (3D printing): A review of materials, methods, applications and challenges. Composites Part B, Vol. 35, 101388.

8. Singh A., Kapil S., Das M. (2020). A comprehensive review of the methods and mechanism for powder feedstock handing in direct energy deposition. Additive Manufacturing, Vol. 35, 101388.

9. Thompson A.M., Bian L., Shamsaei N., Yadollahi A. (2015). An overview of Direct Laser Deposition for additive manufacturing. Part I: Transport phenomena, modeling and diagnostics. Additive Manufacturing, Vol. 8, pp. 36-62.

10. Shamsaei N., Yadollahi A., Bian L., Thopson S.M. (2015). An overview of Direct Laser Deposition for additive manufacturing. Part II: Mechanical behaviour, process parameter optimization and control. Additive Manufacturing, Vol. 8, pp. 12-35.

11. Gipson I., Rosen D., Brent S. (2015). Direct Energy Deposition Processes. In Additive Manufacturing Technologies: 3D Printing, Rapid Prototyping, and Direct Digital Manufacturing (Gipson I., Rosen D., Brent S., Eds.). Springer, New York, USA, pp. 245-268.

12. Madrid A.P.M., Vrech S.M., Sanchez M.A. (2019). Advances in additive manufacturing for bone tissue engineering scaffolds. Material Science \& Engineering $C$, Vol. 100, pp. 631-644.

13. Daminabo S.C., Goel S., Grammatikos S.A., Nezhad H.Y., Thakur V.K. (2020). Fused deposition modelingbased additive manufacturing (3D printing): techniques for polymer material systems. Materials Today Chemistry, Vol. 16, 100248.

14. Gipson I., Rosen D., Brent S. (2015). Extrusion-Based Systems. In Additive Manufacturing Technologies: 3D Printing, Rapid Prototyping, and Direct Digital Manufacturing (Gipson I., Rosen D., Brent S., Eds.). Springer, New York, USA, pp. 147-173.

15. Singh D.D., Mahander T., Reddy A.R. (2021). Powder bed fusion processes: A brief review. Materials Today: Proceedings, Vol. 46, pp. 350-355.

16. Aimar A., Palermo G., Innocenti B. (2019). The Role of 3D Printing on Medical Applications: A State of the Art. Journal of Healthcare Engineering, Vol. 10.

17. Javaid M., Haleem A. (2018). Additive manufacturing applications in medical cases: A literature-based review. Alexandria Journal of Medicine, Vol. 54, pp. 411-422.

18. Ahangar P., Cooke M.E., Weber M.H., Rosenzweig D. (2019). Current Biomedical Applications of 3D Printing and Additive Manufacturing. Applied Science, Vol. 9, 1713.

19. Harris R., Savalani M. (2005). Medical Applications. In Rapid Manufacturing: An Industrial Revolution for Digital Age (Hopkinson N., Hague R. Dicens, P., Eds.). Jon Wiley \& Sons, Hoboken, USA.

20. Tuomi J., Palohemio K.-S., Vehvilainen J., Bjorkstrand R., Salmi M., Houtilainen E., Kontio R., Rouse S., Gibson I., Makitie A.A. (2014). A Novel Classification and Online Platform for Planning and Documentation of Medical Applications of Additive Manufacturing. Surgical Innovation, Vol. 21, pp. 553-559.

21. Piekoś J., Dominiak K., Siemiński, P. (2016). The application of free versions of programs to printing models of bones. Mechanik, Vol. 4, pp. 320-321.

22. Popov V.V., Muller-Kamskii G., Kovalevsky A. Dzhenzhera G., Strokin E., Kolomiets A., Ramon J.
(2018). Design and 3D-printing of titanium bone implants: brief review of approach and clinical cases. Biomedical Engineering Letters, Vol. 8, pp. 337-344.

23. Ganguli A., Pagan-Diaz G.J., Grant L., Cvetkovic C., Bramlet M., Vozenilek J., Kesavadas T., Bashir R. (2018). 3D printing for preoperative planning and surgical training: a review. Biomedical Microdevices, Vol. 20, 65 .

24. Tong Y., Kaplan D.J., Spivak J.M., Bendo J.A. (2020). Three-dimensional printing in spine surgery: a review of current applications. The Spine Journal, Vol. 20, pp. 833-846.

25. Bruns J., Habermann C.R., Ruther W., Delling D. (2010). The use of CT derived solid modelling of the pelvis in planning cancer resection. European Journal of Surgical Oncology, Vol. 36, pp. 594-598.

26. Jiang, N., Hsu Y., Khadka A., Hu J., Wang D., Wang Q., Li J. (2012). Total or partial inferior border ostectomy for mandibular: Indications and outcomes. Journal of Cranio-Maxillofacial Surgery, Vol. 40, pp. 277-284.

27. Feber J., Berto P.M., Quaresma M. (2006). Rapid prototyping as a tool for diagnosis and treatment planning for maxillary canine impaction. American Journal of Orthodontics and Dentofacial Orthopedics, Vol. 129, pp. 583-589.

28. Mishra A., Verma T., Vaish A.,; Vaish R., Vaishya R., Maini L. (2019). Virtual preoperative planning and 3D printing are valuable for the management of complex orthopaedic trauma. Chinese Journal of Traumatology, Vol. 22, pp. 350-355.

29. Culmore C., Smit G., Breedveld P. (2019). Additive manufacturing of medical instruments: A state-of-art review. Additive Manufacturing, Vol. 27, pp. 461-473.

30. Paramasivam V., Sindhu Singh G., Santhanakrishnan S. (2020). 3D Printing of Human Anatomical Models for Preoperative Surgical Planning. Procedia Manufacturing, Vol. 48, pp. 684-690.

31. Bittner S.M., Guo J.L., Melchiorri A., Mikos A.G. (2018). Three-dimensional printing of multilayer tissue engineering scaffolds. Materials Today, Vol. 21, pp. 861-874.

32. Turnbull G., Clarke J., Picard F., Zhang W., Riches P., Li B., Shu W. (2020). 3D biofabrication for soft tissue a cartilage engineering. Medical Engineering and Physics, Vol. 82, pp. 13-39.

33. Zafar M.J., Zhu D., Zhang Z. (2019). 3D Printing of Bioceramics for Bone Tissue Engineering. Materials, Vol. 12, 3361.

34. Liu F-H., Lee R-T., Lin W-H., Liao Y-S. (2013). Selective laser sintering of bio-metal scaffolds. Procedia CIRP, Vol. 5, pp. 83-87.

35. Putri N.R., Wang X., Chen Y., Li X., Kawazoe N. (2020). Preparation of PLGA-collagen hybrid scaffolds with controlled pore structures for cartilage tissue engineering. Progress in Natural Science: Materials International, Vol. 5, pp. 642-650.

36. Sherwood J.K., Riley S.L., Palazzolo R., Brown S.C, Monkhouse C., Coates M., Griffith L.G., Landeen L.K., Ratcliffe A. (2002). A tree-dimensional osteochondral composite scaffold for articular cartage repair. Biomaterials, Vol. 23, pp. 4739-4751.

37. Camarero-Espinosa S., Tomasina C., Calore A., Moroni L. (2020). Additive manufactured, highly resilient, elastic, and biodegradable poly(ester)urethane scaffold with contraindicative properties for cartilage tissue engineering. Materials Today Bio, Vol. 6, 100051.

38. Park C.H., Rios H.F., Jin, Q., Bland M.E., Flanagan C.L., Hollister S.J., Giannobile W.V. (2010). Biomimetic hybrid scaffold for engineering human tooth-ligament interfaces. Biomaterials, Vol. 31, pp. 5945-5952. 
39. Cui X., Boland T. (2009). Human microvasculature fabrication using thermal inkjet printing technology. Biomaterials, Vol. 31, pp. 6221-6227.

40. Lowther M., Louth S., Davey A., Hussain A., Ginestra P., Carter L., Einstein N., Grover L., Cox S. (2019). Clinical, industrial, and research perspective on powder bed fusion additively manufactured metal implants. Additive Manufacturing, Vol. 26, pp. 565-584.

41. Harun W.S.W., Kamariah M.S.I.N., Muhamad N., Ghani S.A.C., Ahamd F., Mohamed Z. (2018). A review of powder additive manufacturing process for metallic biomaterials. Powder Technology, Vol. 327, pp. 128151.

42. Sing S.L., An J., Yeong W.Y., Wiria F.E. (2016). Laser and Electron-Beam Powder-Bed Additive Manufacturing of Metallic Implants: A Review on Processes, Materials and Design. Journal of Orthopedic Research, Vol. 34, pp. 369-385.

43. Burton H.E., Einstein N.M., Lawless B.M., Jamshidi P., Segarra M.A., Addison O., Shepherd D.E.T., Attallah M.M., Grover L.M., Cox S.C. (2019). The design of additively manufactured lattices to increase the functionality of medical implants. Material Science \& Engineering C, Vol. 94, pp. 901-908.

44. Zamborsky R., Kilian M., Jacko P., Bernadic M., Hudak R. (2019). Perspectives of 3D printing technology in orthopaedic surgery. Bratislava Medical Journal, Vol. 120, pp. 498-504.

45. Javaid M., Haleem A. (2019). Current status and applications of additive manufacturing in dentistry: A literature-based review. Journal of Oral Biology and Craniofacial Research, Vol. 9, pp. 179-185.

46. Revilla-Leon M., Sadeghpour M., Ozcan M. (2020). A Review of the Applications of Additive Manufacturing Technologies Used to Fabricate Metals in Implant Dentistry. Journal of Prosthodontics, Vol. 9, pp. 179-185.

47. Oliviera T.T., Reis A.C. (2019). Fabrication of dental implants by the additive manufacturing method: A systematic review. The Journal of Prosthetic Dentistry, Vol. 122, pp. 270-274.

48. Kunrath M.F. (2020). Customized dental implants: Manufacturing processes, topography, osteointegration and future perspectives of 3D fabricated implants. Bioprinting, Vol. 20, e00107.

49. Galante R., Figueiredo-Pina C.G., Serro A.P. (2019). Additive manufacturing of ceramics for dental applications: A review. Dental materials, Vol. 35, pp. 825-846.

50. Mangano C., Bianchi A., Mangano F.G., Dana J., Colombo M., Solop I., Admakin O. (2020). Custommade 3D printed subperiosteal titanium implants for the prosthetic restoration of the atrophic posterior mandible of elderly patients: a case series. $3 D$ Printing in Medicine, Vol. 6, 1.

51. Figliuzzi M., Mnagano F., Mangano C. (2012). A novel root analogue dental implant using $\mathrm{CT}$ scan and CAD/CAM: selective laser melting. Oral and Maxillofacial Surgery, Vol. 41, pp. 858-862.

52. Zhang Y., Zhang L., Sun R., Jia Y., Chen X., Liu Y., Oyang H., Feng L. (2018). A new 3D printed titanium metal trabecular bone reconstruction system for early osteonecrosis of the femoral head. Medicine, Vol. 97, pp. e11088-e11096.

53.Wang X., Xu H., Zhang J. (2019). Using personalized 3D printed Titanium sleeve-prosthetic composite for the reconstruction of severe segmental bone loss of proximal femur in revision total hip arthroplasty. Medicine, Vol. 99, pp. e18784-e18789.

\section{Biographical notes}

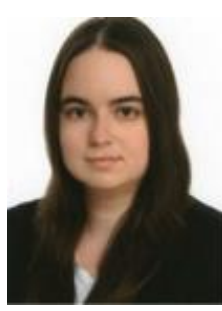

Dorota Laskowska received her M.Sc. degree in Mechatronics from Koszalin University of Technology. Currently a Ph.D. student in Mechanical Engineering at the Koszalin University of Technology. In her Ph.D. thesis she focuses on mechanical and surface properties of elements produced in additive manufacturing from metal powder.

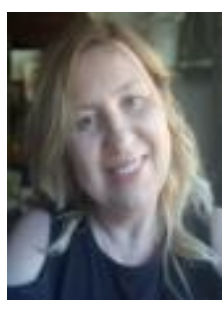

Katarzyna Mitura her scientific achievements include the scope of interactions between carbon-based materials and nanomaterials in contact with the environment of a living organism (in vitro tests on cell lines, in vivo tests on animals, in ovo tests (hen egg embryo), human clinical trials as well as micobiological on pathogens).

Recent publications and book chapters concern the application of carbon nanostructures in the packaging, food and environmental engineering industries. Her scientific achievements are in the field of technical sciences and medical sciences in the discipline of biomedical engineering and materials engineering.

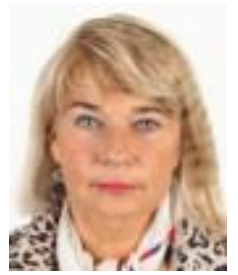

Ewa Ziólkowska is professor at Faculti of Health Science of Calisia University. Her scientific interests focus on problems of radiotherapy and oncological treatment of brain tumor, hed and neck cancer and prostate cancer. In her research work she focus on focuses on the use of modern treatment techniques using by nanotechnology and 3D printing.

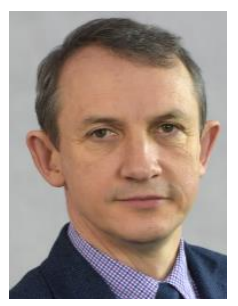

Błażej Bałasz is vice-rector of Koszalin University of Technology and head of the Rapid Prototyping Center of the Faculty of Mechanical Engineering. His scientific interests focus on the use of large data sets for machine and device diagnostics as well as modeling and simulation of industrial processes and designing technological processes. Together with the team of the Rapid Prototyping Center, he conducts works on the development of the technology of additive manufacturing of machine parts from metal powders applicable in machine construction, energy and biomedical engineering. His achievements include over 100 scientific publications. He was a manager or contractor in 12 research projects 
